\title{
DEVELOPMENT AND VALIDATION OF FTIR SPECTROPHOTOMETRY TO IDENTIFY AND DETERMINE CHLORAMPHENICOL IN MARKETED CAPSULES
}

\author{
Nerdy Nerdy ${ }^{1,}$, Linda Margata ${ }^{1}$, Christica Ilsanna Surbakti ${ }^{1}$, Effendy De \\ Lux Putra ${ }^{2}$, Masna Arisah Nasution ${ }^{2}$ and Tedy Kurniawan Bakri ${ }^{3}$ \\ ${ }^{1}$ Department of Pharmacy, Faculty of Pharmacy, Institut Kesehatan Deli Husada Deli Tua, Deli \\ Tua Timur, Deli Tua, Deli Serdang, Sumatera Utara, Indonesia, 20355 \\ ${ }^{2}$ Department of Pharmacy, Faculty of Pharmacy, Universitas Sumatera Utara, Padang Bulan, \\ Medan Baru, Medan, Sumatera Utara, Indonesia, 20155 \\ ${ }^{3}$ Department of Pharmacy, Faculty of Mathematics and Natural Sciences, Universitas Syiah \\ Kuala, Kopelma Darussalam, Syiah Kuala, Banda Aceh, Aceh, Indonesia, 23111 \\ ${ }^{\square}$ Corresponding Author: nerdy190690@gmail.com
}

\begin{abstract}
Chloramphenicol is an antibiotic compound that inhibits bacterial protein synthesis. All pharmaceutics in the form of finished goods and raw materials must meet the requirements of Indonesian Pharmacopoeia or other standard books. The objectives of this study were to develop and validate a simple and fast analytic method by Fourier Transform Infrared (FTIR) spectrophotometry that allows for qualitative and quantitative analysis of chloramphenicol levels in capsule preparations. Chloramphenicol levels were determined by FTIR analysis using methanol solvents with 0.1 $\mathrm{mm}$ slit in the wavenumber range $4000 \mathrm{~cm}^{-1}$ to $650 \mathrm{~cm}^{-1}$. The specific wavenumbers of chloramphenicol solution in methanol were $1695.9 \mathrm{~cm}^{-1}, 1526.3 \mathrm{~cm}^{-1}$, and $1351.2 \mathrm{~cm}^{-1}$. Peak height analysis was not significantly different from peak area analysis, and all samples analyzed fulfilled the requirements of the Indonesian Pharmacopoeia, $6^{\text {th }}$ Edition (2020). Analytical validation met requirements for accuracy, precision, linearity, the limit of detection, the limit of quantitation, range, and specificity. The study concludes that identification and determination of chloramphenicol can be conducted by FTIR with simple preparation and fast results.
\end{abstract}

Keywords: Development, Validation, Identification, Determination, Fourier Transform Infrared (FTIR), Chloramphenicol

RASĀYAN J. Chem., Vol. 14, No.3, 2021

\section{INTRODUCTION}

Chloramphenicol is an antibiotic compound that was isolated from Streptomyces venezuelae in 1947; it inhibits bacterial protein synthesis. ${ }^{1}$ This compound is generally bacteriostatic and bactericidal to various types of gram positive and gram negative bacteria. It is usually used in the form of capsules because it tastes very bitter. ${ }^{2}$ Chloramphenicol is used in the treatment of typhoid fever because it is effective, inexpensive, and can be administered orally. ${ }^{3}$

All pharmaceutical preparations and raw materials must meet the requirements of the Indonesian Pharmacopoeia or other standard books. Quality control ensures that manufactured drugs meet quality requirements in accordance with their intended use. ${ }^{4}$ According to the Indonesian Pharmacopoeia $\left(6^{\text {th }}\right.$ edition), chloramphenicol capsules should contain no less than $90.0 \%$ and no more than $120.0 \%$ of the amount stated on the label. ${ }^{5}$

Identification and determination of chloramphenicol in capsules are generally conducted using highperformance liquid chromatography, however, the method is expensive, time-consuming, and more complicated than other techniques. ${ }^{6}$ Thus, it is necessary to develop methods for chloramphenicol analysis that are cheaper, simpler, and easier to perform. FTIR is a suitable method for drug identification and determination because it provides good sensitivity, is simple to prepare, and is quickly measured. ${ }^{7}$ 
RASĀYAN J. Chem.

Vol. 14 | No. 3 |1558-1564| July - September | 2021

FTIR in the pharmaceutical industry is very popular as a qualitative and quantitative tool because it requires simple sample preparation and allows for non-destructive measurement. Such features are optimal for monitoring the quality and quantity of raw materials and finished goods. ${ }^{8}$ FTIR also minimizes environmental impacts, such as industrial chemical waste, because it does not require many solvents. ${ }^{9}$ This study aimed to develop a simpler, cheaper, faster, and more environmentally friendly method for qualitative and quantitative analysis of chloramphenicol in capsule preparations using the Fourier Transform Infrared spectroscopic method.

\section{EXPERIMENTAL}

\section{Tools}

In this study, the researchers used a complete Fourier Transform Infrared Spectrophotometer with Dialpath (Agilent - Cary 630), Personal Computer (Lenovo) with Microlab (Agilent) and Statistical Package for the Social Sciences (International Business Machines), Printer (Canon), Analytic Balance (Sartorius), filter paper (Whatman), Tissue Paper (Paseo), Electronic Pipette (Eppendorf - Multipette E3X), Sonicator (Krisbow), and Glassware (Iwaki).

\section{Materials}

The researchers used Methanol Analytical Grade (Merck), Chloramphenicol Working Standard (Mutiara Mukti Farma), Chloramphenicol capsules (Holi Pharma), Chloramphenicol capsules (Kimia Farma), Chloramphenicol capsules (Mutiara Mukti Farma), Etagemycetin ${ }^{\circledR}$ capsules (Errita Pharma), Kalmicetine ${ }^{\circledR}$ capsules (Kalbe Farma), Colsancetine ${ }^{\circledR}$ capsules (Sanbe Farma), Hufamycetin ${ }^{\circledR}$ capsules (Gratia Husada Farma), Erbacetine ${ }^{\circledR}$ capsules (Mutiara Mukti Farma).

\section{Sampling}

Sampling was done by purposive sampling without comparing one characteristic to another, as the sample is considered homogeneous.

\section{Qualitative and Quantitative Analysis of Chloramphenicol}

The identification and the determination of chloramphenicol in marketed capsules was modified from methods described in Robaina et al., 2013. The analytical procedures include preparation of the stock solution, preparation of absorption spectrum, preparation of the calibration curve, and determination of chloramphenicol capsule levels. ${ }^{10}$

\section{Preparation of Stock Solution}

Chloramphenicol working standard was weighed at $2.5 \mathrm{~g}$ and inserted into a $50 \mathrm{~mL}$ volumetric flask to which $30 \mathrm{~mL}$ methanol was added. The result was sonicated for 15 minutes and methanol was added to the marked line. The flask was shaken until homogeneous (concentration of chloramphenicol was $50 \mathrm{mg} / \mathrm{mL}$ ).

\section{Preparation of Absorption Spectrum}

$5 \mathrm{~mL}$ stock solution was pipetted into a $10 \mathrm{~mL}$ volumetric flask, to which methanol was added to the marked line. The flask was shaken until homogenous (concentration of chloramphenicol was $25 \mathrm{mg} / \mathrm{mL}$ ). The absorbance of the solution in methanol was measured between wavenumber $4000 \mathrm{~cm}^{-1}$ to $650 \mathrm{~cm}^{-1}$. The spectrum was overlaid to obtain the specific peak of chloramphenicol.

\section{Preparation of Calibration Curve}

Standard solutions of chloramphenicol were prepared in a $10 \mathrm{~mL}$ volumetric flask to obtain a concentration series from 5 to $45 \mathrm{mg} / \mathrm{mL}$ in $5 \mathrm{mg}$ intervals. This was achieved by pipetting 1 to $9 \mathrm{~mL}$ of chloramphenicol stock solutions in $1 \mathrm{~mL}$ intervals, adding methanol to the marked line, shaking until homogenous, and measuring the spectrum for 11 concentrations from 0 to $50 \mathrm{mg} / \mathrm{mL}$. (The concentration $0 \mathrm{mg} / \mathrm{mL}$ used methanol and the $50 \mathrm{mg} / \mathrm{mL}$ used chloramphenicol stock solution). Researchers analyzed the height and area at the chloramphenicol specific peak, then calculated the determination coefficient and regression equation. 
RASĀYAN J. Chem.

Vol. 14 | No. 3 |1558-1564| July - September | 2021

\section{Determination of Chloramphenicol Capsule Levels}

Twenty capsules were weighed, mixed until homogenous, made equivalent to $250 \mathrm{mg}$ chloramphenicol, and inserted into a $10 \mathrm{~mL}$ volumetric flask. $6 \mathrm{~mL}$ methanol was added, and the result was sonicated for 15 minutes. Methanol was added to the marked line and shaken until homogenous. The mixture was filtered to remove $1 \mathrm{~mL}$ of the first filtrate. The following filtrate was collected, (the predicted concentration of chloramphenicol was $25 \mathrm{mg} / \mathrm{mL}$ ). Researchers then measured the spectrum, calculated the height at the chloramphenicol specific peak, and calculated the chloramphenicol level in capsule preparations using the obtained regression equation.

\section{Validation of the Method}

Validation of FTIR analysis was modified from procedures by Nugrahani and Mussadah, 2016; and Sopyan et al., 2020. Method accuracy was measured by the percentage of recovery in three specific ranges $(80 \%$, $100 \%$ and $120 \%$ ) with $70 \%$ of the analyzed sample and $30 \%$ of chloramphenicol working standard added (standard addition method). Precision by relative standard deviation was calculated from series of accurate data. Linearity by a correlation coefficient, detection limits, and quantitation limits was calculated from the calibration curve data series. The range was analyzed by concentration, indicating accuracy, precision, linearity, the limit of detection, and the limit of quantitation. Method specificity was analyzed by qualitative results from the sample analysis. ${ }^{11,12}$

\section{RESULTS AND DISCUSSION}

\section{Determination of Chloramphenicol Specific Wavenumber}

Research began by determining the absorption spectrum of methanol. The methanol absorption spectrum can be seen in Fig.-1.

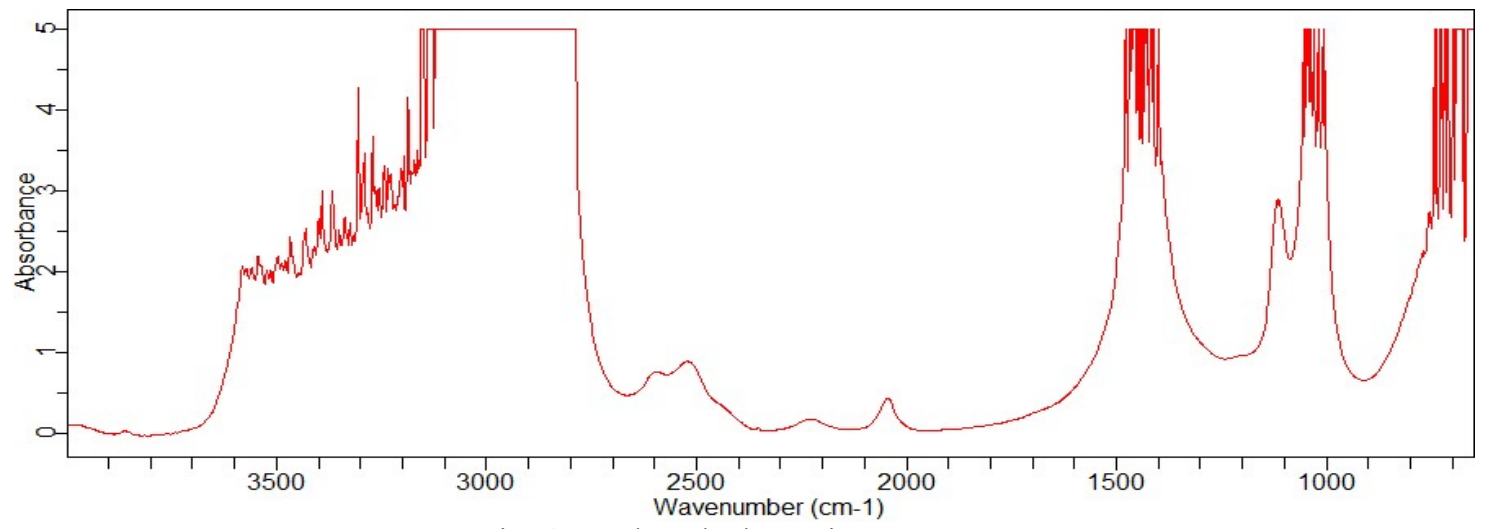

Fig.-1: Methanol Absorption Spectrum

The chloramphenicol absorption spectrum with a concentration of $25 \mathrm{mg} / \mathrm{mL}$ in methanol was then determined. The chloramphenicol absorption spectrum with a concentration of $25 \mathrm{mg} / \mathrm{mL}$ in methanol can be seen in Fig.-2.

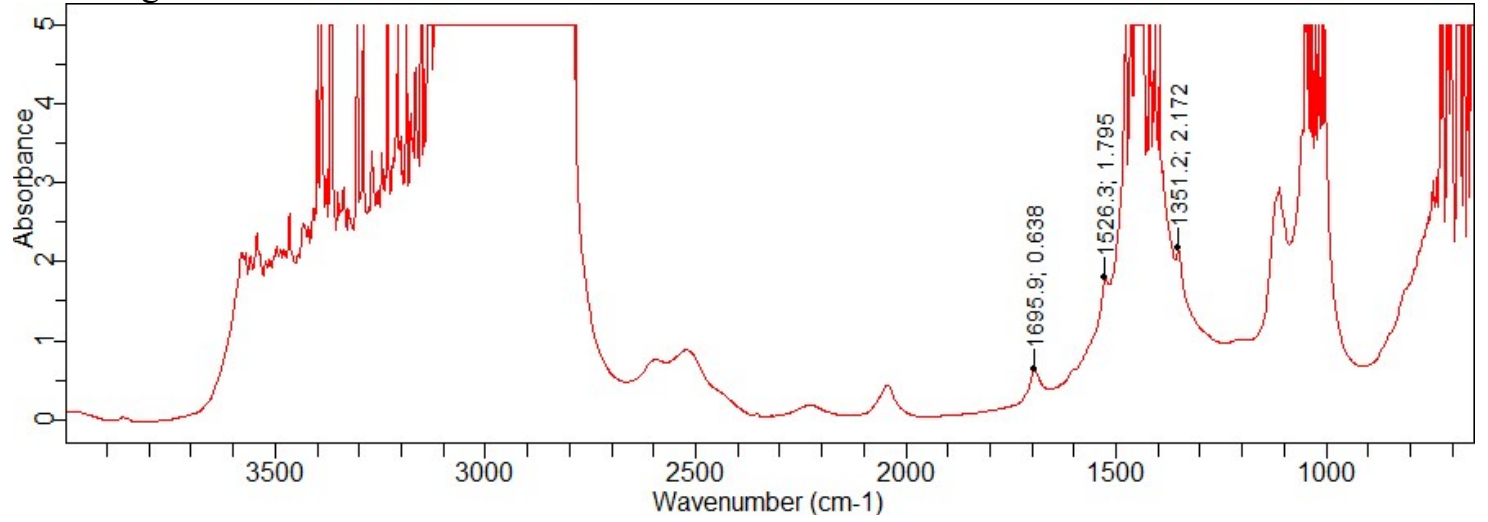

Fig.-2: Chloramphenicol Absorption Spectrum with a Concentration of $25 \mathrm{mg} / \mathrm{mL}$ in Methanol 
RASĀYAN J. Chem.

Vol. 14 | No. 3 |1558-1564| July - September | 2021

Infrared spectrophotometry can be used for qualitative analysis, wherein each molecule produces a different absorption spectrum. ${ }^{13}$ The specific absorption wavenumber of chloramphenicol from methanol is achieved by overlaying the spectra of methanol and chloramphenicol in methanol. The overlaid spectra are in Fig.3 .

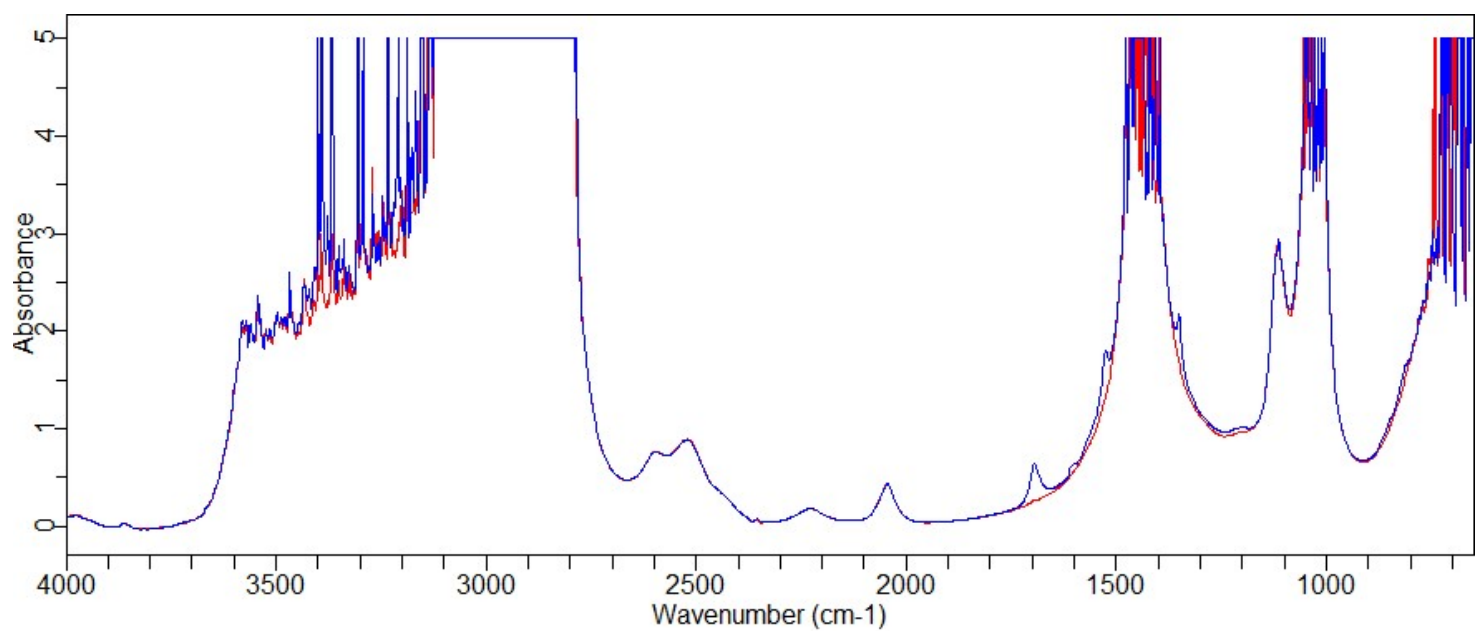

Fig.-3: Display of Overlapping Spectra of Methanol and Chloramphenicol Absorption (25 mg/ml) in Methanol

There is a significant difference between the absorption spectrum of methanol and chloramphenicol in methanol, as shown at wavenumbers $1695.9 \mathrm{~cm}^{-1}, 1526.3 \mathrm{~cm}^{-1}$, and $1351.2 \mathrm{~cm}^{-1}$. The wavenumber is specific to chloramphenicol and not to methano ${ }^{14}$. Thus, qualitative and/or quantitative analysis can be carried out at these wavenumbers. The peaks at wavenumbers $1526.3 \mathrm{~cm}^{-1}$ and $1351.2 \mathrm{~cm}^{-1}$ was very unique for chloramphenicol, thus they are best suited for qualitative testing. The peak at wavenumber $1695.9 \mathrm{~cm}^{-1}$ has the highest peak height, indicating it is best suited for quantitative determination.

\section{Determination of Chloramphenicol Regression Equation}

The absorption spectrum of chloramphenicol with a series concentration $(0 \mathrm{mg} / \mathrm{mL}$ to $50 \mathrm{mg} / \mathrm{mL})$ in methanol can be seen in Fig.-4.

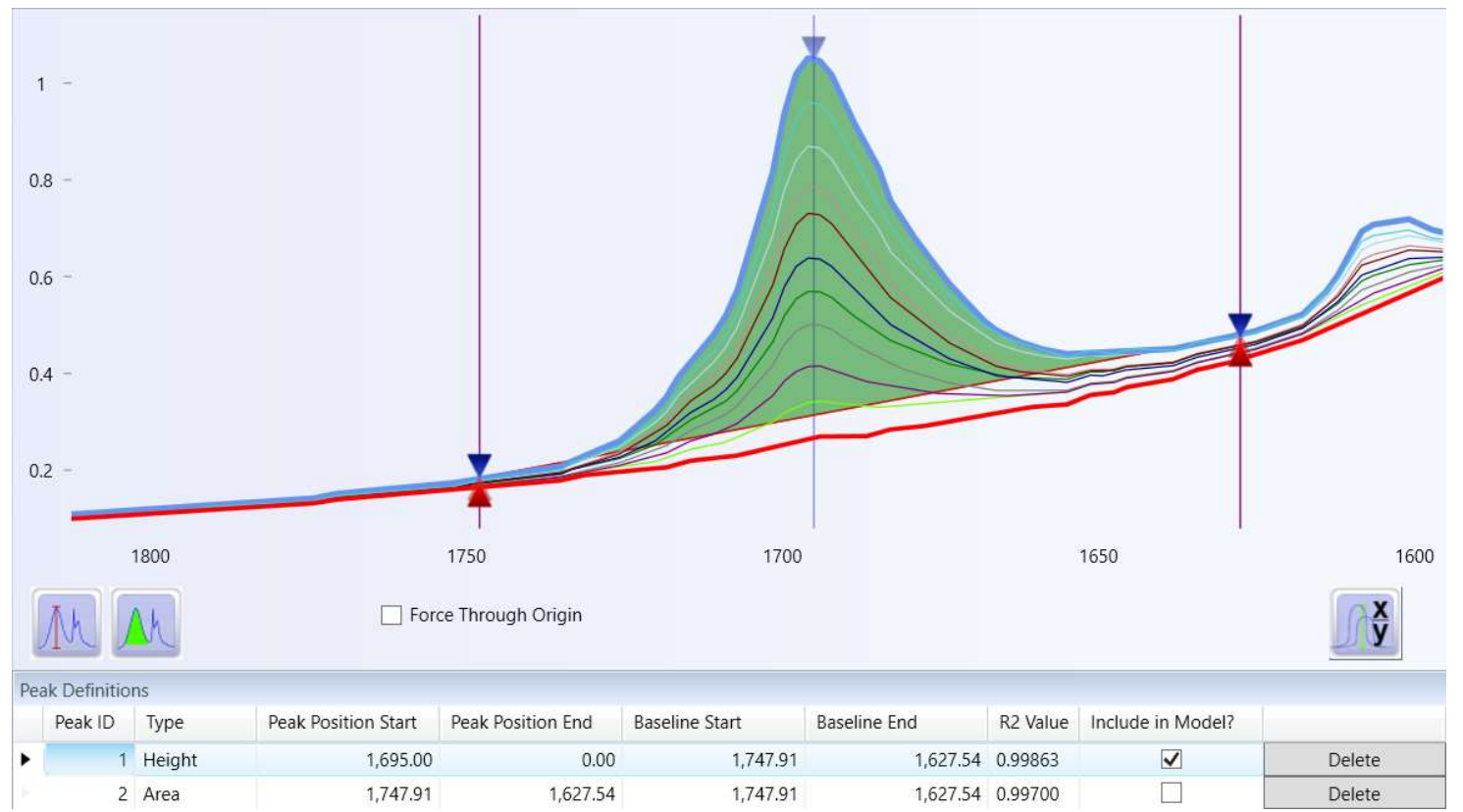

Fig.-4: Absorption Spectrum of Chloramphenicol with Series Concentration ( $0 \mathrm{mg} / \mathrm{mL}$ to $50 \mathrm{mg} / \mathrm{mL})$ in $\mathrm{Methanol}$ 
RASĀYAN J. Chem.

Vol. 14 | No. 3 |1558-1564| July - September | 2021

The spectrum of chloramphenicol at various concentrations in methanol shows that concentration does not change the shape of the spectrum, but only changes the peak absorbance (peak height and peak area). The graph indicates that higher concentrations result in higher and larger peaks. Thus, peak height and area can be used as the basis for quantitative analysis. ${ }^{15}$ The chloramphenicol regression equations obtained were $\mathrm{Y}$ $=0.01498 \mathrm{X}+0.09785$ for peak height and $\mathrm{Y}=0.50454 \mathrm{X}+13.95957$ for peak area range. The chloramphenicol determination coefficients obtained were 0.999 for peak height and 0.997 for peak area.

Qualitative Identification and Quantitative Determination of Chloramphenicol in Capsules

The qualitative identification and quantitative determination of chloramphenicol in capsules, with calculations by peak height and peak area seen in Table-1.

Table-1: Qualitative Identification and Quantitative Determination of Chloramphenicol in Capsules

\begin{tabular}{|c|c|c|c|}
\hline \multirow{2}{*}{ Samples } & \multirow{2}{*}{ Qualitative } & \multicolumn{2}{|c|}{ Quantitative } \\
\hline & & Peak Height & Peak Area \\
\hline $\begin{array}{l}\text { Chloramphenicol capsules (Holi } \\
\text { Pharma) }\end{array}$ & Passed & $\begin{array}{c}102.22 \% \pm \\
0.92 \%\end{array}$ & $\begin{array}{c}101.88 \% \pm \\
0.99 \%\end{array}$ \\
\hline $\begin{array}{l}\text { Chloramphenicol capsules (Kimia } \\
\text { Farma) }\end{array}$ & Passed & $\begin{array}{c}100.75 \% \pm \\
0.91 \%\end{array}$ & $\begin{array}{c}100.21 \% \pm \\
0.97 \%\end{array}$ \\
\hline $\begin{array}{l}\text { Chloramphenicol capsules (Mutiara } \\
\text { Mukti Farma) }\end{array}$ & Passed & $\begin{array}{c}101.38 \% \pm \\
0.91 \%\end{array}$ & $\begin{array}{c}100.67 \% \pm \\
0.98 \%\end{array}$ \\
\hline $\begin{array}{c}\text { Etagemycetin }{ }^{\circledR} \text { capsules (Errita } \\
\text { Pharma) }\end{array}$ & Passed & $99.88 \% \pm 0.90 \%$ & $\begin{array}{c}100.26 \% \pm \\
0.97 \%\end{array}$ \\
\hline $\begin{array}{c}\text { Kalmicetine }{ }^{\mathbb{R}} \text { capsules (Kalbe } \\
\text { Farma) }\end{array}$ & Passed & $\begin{array}{l}101.24 \% \pm \\
0.91 \%\end{array}$ & $\begin{array}{c}100.84 \% \pm \\
0.98 \%\end{array}$ \\
\hline $\begin{array}{c}\text { Colsancetine }^{\circledR} \text { capsules (Sanbe } \\
\text { Farma) }\end{array}$ & Passed & $\begin{array}{c}102.19 \% \pm \\
0.92 \% \\
\end{array}$ & $\begin{array}{c}101.83 \% \pm \\
0.99 \% \\
\end{array}$ \\
\hline $\begin{array}{c}\text { Hufamycetin }^{\circledR} \text { capsules (Gratia } \\
\text { Husada Farma) }\end{array}$ & Passed & $\begin{array}{c}100.56 \% \pm \\
0.91 \%\end{array}$ & $99.93 \% \pm 0.97 \%$ \\
\hline $\begin{array}{c}\text { Erbacetine }^{\circledR} \text { capsules (Mutiara Mukti } \\
\text { Farma) }\end{array}$ & Passed & $98.21 \% \pm 0.88 \%$ & $99.04 \% \pm 0.96 \%$ \\
\hline
\end{tabular}

\section{Validation of Developed Method}

The average percentage of the recovery obtained was $100.06 \% \pm 0.59 \%$ based on peak height calculation and $100.09 \% \pm 0.63 \%$ based on peak height calculation. The results for accuracy met the requirements of the average percentage of recovery between $98 \%$ to $102 \% .^{16,17}$ The relative standard deviation of chloramphenicol obtained was $0.59 \%$ based on peak height calculation and $0.63 \%$ based on peak height calculation. Results for precision met requirements for a relative standard deviation less than $2 \% .{ }^{18,19}$

The chloramphenicol correlation coefficient obtained was 0.999 based on peak height calculation and 0.999 based on peak area calculation. The correlation coefficient value of the $r$ table was 0.847 , calculated with a confidence level of $99.9 \%$ with 11 series concentrations (at 9 degrees of freedom. The correlation coefficient value was not less than 0.847 , showing that there was a linear correlation between chloramphenicol concentration and response (peak height or peak area). ${ }^{20}$ The correlation coefficient value obtained indicated a very strong correlation with a value greater than $0.99 .21,22$

The limit of detection for chloramphenicol was $0.663 \mathrm{mg} / \mathrm{mL}$ based on peak height calculation and 0.980 $\mathrm{mg} / \mathrm{mL}$ based on peak area calculation. The limit of quantitation for chloramphenicol was $2.010 \mathrm{mg} / \mathrm{mL}$ based on peak height calculation and $2.969 \mathrm{mg} / \mathrm{mL}$ based on peak area calculation. The concentration used for the analysis was $25 \mathrm{mg} / \mathrm{mL}$, which is much higher than the detection limit value and quantitation limit value. Thus, it can be concluded that chloramphenicol can be detected with this method at a concentration of $25 \mathrm{mg} / \mathrm{mL}$. Furthermore, chloramphenicol can be quantitated at a concentration $25 \mathrm{mg} / \mathrm{mL}$; the method has a low enough detection limit value for qualitative analysis and has a low enough quantitation limit value for quantitative analysis..$^{23,24}$

The range of analysis - accuracy, precision, linearity, the limit of detection, and the limit of quantitation ranged from $20 \mathrm{mg} / \mathrm{mL}(80 \%)$ to $30 \mathrm{mg} / \mathrm{mL}(120 \%)$, which covers the literature requirement. ${ }^{25,26}$ Via FTIR, 
RASĀYAN J. Chem.

Vol. 14 | No. 3 |1558-1564| July - September | 2021

the specific peaks of chloramphenicol were detected from various chloramphenicol capsules and good qualitative results with different matrices were achieved. This indicates appropriate specificity using the FTIR analytical method. ${ }^{27,28}$

\section{CONCLUSION}

Identification qualitative testing and determination by quantitative testing of chloramphenicol capsules can be achieved by Fourier Transform Infrared spectrophotometry. The method uses simple sample preparation and achieves fast results. The qualitative and quantitative tests of chloramphenicol samples in marketed capsule preparations correctly identified and determined the presence of chloramphenicol, fulfilling the requirements in the Indonesian Pharmacopoeia for chloramphenicol content in capsule preparations. The developed method has been validated and shows appropriate results for the accuracy, precision, linearity, limit of detection, the limit of quantitation, range, and specificity required.

\section{ACKNOWLEDGEMENT}

The authors would like to thank the Institut Kesehatan Deli Husada Deli Tua for funding this research and Mutiara Mukti Farma Industri Farmasi for providing tools and materials.

\section{REFERENCES}

1. M. Rahman, and S.D. Sarker, Annual Reports in Medicinal Chemistry, 55, 1(2020), https://doi.org/10.1016/bs.armc.2020.06.001

2. G.P. Dinos, C.M. Athanassopoulos, D.A. Missiri, P.C. Giannopoulou, J.A. Vlachogiannis, G.E. Papadopoulos, D. Papaioannou, and D.L. Kalpaxis. Antibiotics, 5(2), 20(2016), https://doi.org/10.3390/antibiotics5020020

3. E.S. Dasopang, F. Hasanah, T.K. Bakri, and M. Isma, Open Access Macedonian Journal of Medical Sciences, 7(22), 3847(2019), https://doi.org/10.3889/oamjms.2019.517

4. S. Satibi, F.A. Copalcanty, E. Tuko, and L.G. Sawatiandari, International Journal of Scientific \& Technology Research, 9(4), 3034(2020).

5. Ministry of Health (Republic of Indonesia), Indonesian Pharmacopoeia, Ministry of Health, Jakarta, p.906(2020).

6. S.R. Vare, M.M. Shelke, S.M. Gholap, J.S. Bidkar, and G.Y. Dama, World Journal of Pharmaceutical Research, 8(6), 502(2019), https://doi.org/10.20959/wjpr20196-14926

7. A. Brangule, R. Šukele, and D. Bandere. Frontiers in Plant Science, 11, 356(2020), https://doi.org/10.3389/fpls.2020.00356

8. M. Ali, S.T.H. Sherazi, and S.A. Mahesar, Arabian Journal of Chemistry, 7(6), 1104(2014), https://doi.org/10.1016/j.arabjc.2012.09.003

9. S. Fanelli, A. Zimmermann, E.G. Totoli, and H.R.N. Salgado, Journal of Chemistry, 2018, 3920810(2018), https://doi.org/10.1155/2018/3920810

10. N.F. Robaina, C.E.R. de Paula, D.M. Brum, M. de la Guardia, S. Garrigues, and R.J. Cassella, Microchemical Journal, 110, 301(2013), https://doi.org/10.1016/j.microc.2013.04.015

11. I. Nugrahani, and M.V. Mussadah, International Journal of Applied Pharmaceutics, 8(3), 43(2016), https://doi.org/10.22159/ijap.2016v8i3.12946

12. I. Sopyan, D. Dwiputri, and M. Muchtaridi, Rasayan Journal of Chemistry, 13(4), 2207(2020), https://doi.org/10.31788/RJC.2020.1346045

13. A. Matwijczuk, T. Oniszczuk, A. Matwijczuk, E. Chruściel, A. Kocira, A. Niemczynowicz, A. Wójtowicz, M. Combrzynski, and D. Wiacek, Sustainability, 11, 6414(2019), https://doi.org/10.3390/su11226414

14. M.K. Trivedi, S. Patil, H. Shettigar, K. Bairwa, and S. Jana, Pharmaceutica Analytica Acta, 6(7), 395(2015), https://doi.org/10.4172/21532435.1000395

15. Y.Y. Wang, J.Q. Li, H.G. Liu, and Y.Z. Wang, Molecules, 24, 2210(2019), https://doi.org/10.3390/molecules24122210

16. A. Rohman, Indonesian Journal of Pharmacy, 23(1), 1(2012).

17. I. Nugrahani, and N. Dillen, International Journal of Applied Pharmaceutics, 10(4), 43(2018), https://doi.org/10.22159/ijap.2018v10i4.25682 
RASĀYAN J. Chem.

Vol. 14 | No. 3 |1558-1564| July - September | 2021

18. M. dos Santos Silva, K.L. Gonring, R.C.S. da Silva, M.C. Fonseca, M.M.C. Borges, O.C. Nunes, M.R. Forim, K.B. Borges, and W. de Souza Borges, Química Nova, 41(3), 258(2018), https://doi.org/10.21577/0100-4042.20170168

19. A. Rahman, G.J. Sravani, K. Srividya, A.D.R. Priyadharshni, A. Narmada, K. Sahithi, T.K. Sai, and Y. Padmavathi, Journal of Young Pharmacists, 12(2), S51(2020), https://doi.org/10.5530/jyp.2020.12s.46

20. A.P. Asmara, Elkawnie: Journal of Islamic Science and Technology, 2(1), 37(2016), https://doi.org/10.22373/ekw.v2i1.658

21. P. Schober, C. Boer, and L.A. Schwarte, Anesthesia and Analgesia, 126(5), 1763(2018), https://doi.org/10.1213/ANE.0000000000002864

22. H. Akoglu, Turkish Journal of Emergency Medicine, 18, 91(2018), https://doi.org/10.1016/j.tjem.2018.08.001

23. E.L. Ashley, E. Cauda, L.G. Chubb, D.P. Tuchman, E.N. Rubinstein, Annals of Work Exposures and Health, 64(5), 536(2020), https://doi.org/10.1093/annweh/wxaa031

24. A. Westfall, G.T. Sigurdson, L.E. Rodriguez-Saona, and M.M. Giust, Antioxidants, 9, 486(2020), https://doi.org/10.3390/antiox9060486

25. R. Widiastuti, and Y. Anastasia, Tropical Animal Science Journal, 43(3), 270(2020), https://doi.org/10.5398/tasj.2020.43.3.270

26. K.S. Prabhu, A. Venkatachalam, and S. Kale, Rasayan Journal of Chemistry, 13(3), 2020(2020), https://doi.org/10.31788/RJC.2020.1335820

27. P.N. Kulkarni, A.M. Dodake-Supekar, and C.H. Gill, Rasayan Journal of Chemistry, 13(3), 1522(2020), https://doi.org/10.31788/RJC.2020.1335783

28. J. Almeida. M. Bezerra, D. Markl, A. Berghaus, P. Borman, and W. Schlindwein, Pharmaceutics, 12, 150(2020), https://doi.org/10.3390/pharmaceutics12020150

[RJC-6369/2021] 